\title{
Evolutionary pathways in soil-landscape evolution models
}

\author{
W. Marijn van der Meij ${ }^{1}$ \\ ${ }^{1}$ Institute of Geography, University of Cologne, Albertus-Magnus-Platz, 50923 Cologne, Germany \\ Correspondence to: W. Marijn van der Meij (m.vandermeij@uni-koeln.de)
}

\section{Abstract}

Soils and landscapes can show complex, non-linear evolution, especially under changing climate or land use. Soil-landscape evolution models (SLEMs) are increasingly equipped to simulate the development of soils and landscapes over long timescales under these changing drivers, but provide large data output that can be difficult to interpret and communicate. New tools are required to analyse and communicate large model output.

10 In this work, I show how spatial and temporal trends in previously published model results can be summarized and conceptualized with evolutionary pathways, which are possible trajectories of the development of soil patterns. Simulated differences in rainfall and land use control progressive or regressive soil development and convergence or divergence of the soil pattern. These changes are illustrated with real-world examples of soil development and soil complexity.

The use of evolutionary pathways for analysing the results of SLEMs is not limited to the examples in this paper, but they

15 can be used on a wide variety of soil properties, soil pattern statistics and models. With that, evolutionary pathways provide a promising tool to analyse and communicate soil model output, not only for studying past changes in soils, but also for evaluating future spatial and temporal effects of soil management practices in the context of sustainability.

Keywords: soil-landscape evolution model, evolutionary pathways, soil development, sustainable soil management, complexity 


\section{Introduction}

Soils are natural resources that provide valuable functions such as food provision and carbon storage (Adhikari and Hartemink, 2016). Due to intensive land management, these resources are threatened and the resources decline. Understanding how soil and landscape properties are affected by anthropogenic pressure is essential not only to assess the impact of intensive land management on soil functions, but also to develop sustainable management strategies where natural processes can be used to improve the soil functions, such as carbon sequestration (Minasny et al., 2017).

The development, and degradation, of soils is not only something of recent times. Starting with first agriculture and increasing in intensity towards the present, humans have triggered and increased erosion and degradational processes (Dotterweich, 2013; Stephens et al., 2019). A longer-term perspective of centuries to millennia is thus required to understand

30 and describe the dynamics of soil systems in response to anthropogenic pressure. Through time, soil development can follow multiple trajectories, depending on the initial state and the driving forces. A change in land use, for example, will affect soil development differently for different topographic positions (Sommer et al., 2008). These developmental trajectories of soillandscape systems can be described in a conceptual and quantitative way using evolutionary pathways, which were developed and extensively described by professor Jonathan D. Phillips (e.g., Phillips, 2019). A major problem in quantifying these pathways is the need for a large set of spatial and especially temporal soil data. This is often problematic, because measurements only cover a brief period of time and areas where a longer chronological record is present, such as chronosequences, the number of data points is often limited and it is impossible to sample the exact location multiple times without disturbing its development.

Soil-landscape evolution models (SLEMs) can provide a solution here. SLEMs are numerical models that simulate a set of

40 pedogenic and geomorphic processes that affect the spatial and temporal development of soils and landscapes (Minasny et al., 2015). Recent development in SLEMs enable a more accurate simulation of driving forces behind soil and landscape development (e.g., Van der Meij et al., 2018) and with that they become increasingly equipped to simulate soil and landscape development in a wide variety of settings, over long timescales (Bouchoms et al., 2017; Bock et al., 2018; Van der Meij et al., 2020; Welivitiya et al., 2019). These developments make SLEMs suitable not only to study past soil-landscape

45 dynamics, but also to evaluate the effect of future changes in climate and land use on soil and landscape properties, such as carbon and nutrient stocks (Minasny et al., 2015). SLEMs can provide a large amount of spatiotemporal data on soil and landscape properties to calculate the evolutionary pathways. Conversely, evolutionary pathways might be a suitable tool to summarize and visualize the large data output from SLEMs and characterize the development of soil and landscape properties under different drivers.

50 In this study, I test the concept of evolutionary pathways as a new tool to analyze and conceptualize trends in the results of SLEMs. 


\section{Methods}

\subsection{Model study}

55 This study builds further on the results of Van der Meij et al. (2020), who used their SLEM called HydroLorica to simulate the development of soils and landscapes under different rainfall and land use scenarios. A detailed description of the methodology and results is provided in their paper and supplementary information. Here I will briefly repeat the key aspects of the study, that are of importance to this study as well.

The model HydroLorica simulates a set of geomorphic, pedogenic, hydrologic and biotic processes that affect soils in natural

60 and agricultural loamy landscapes. The main difference between HydroLorica and other SLEMs is that it simulates the surface water balance spatially explicit (Van der Meij et al., 2018). Spatial differences in overland flow and infiltration directly control the rates of water erosion and clay translocation. The water stress, determined with a modified Budyko Curve, is used to determine vegetation type (grass or forest). The vegetation type in turn controls rates of bioturbation, soil creep and soil organic matter cycling, and determines water erosion protection by vegetation and the occurrence of tree throw. These processes are thus indirectly controlled by water flow and availability.

The original study simulated three rainfall scenarios: dry $\left(P=300 \mathrm{~mm} \mathrm{a}^{-1}\right)$, humid $\left(P=600 \mathrm{~mm} \mathrm{a}^{-1}\right)$ and wet $\left(P=900 \mathrm{~mm} \mathrm{a}^{-}\right.$ $\left.{ }^{1}\right)$. In this study, I will focus on the dry and wet scenario, where the main natural vegetation types are grasslands and forests, respectively. The simulations were performed in a small artificial catchment as spatial setting to avoid effects of local idiosyncrasies. The parent material is homogeneous loess material of $15 \%$ sand, $75 \%$ silt and $10 \%$ clay. The model runs

70 were 15000 years with an annual timestep. In the first 14500 years of the simulations there was natural soil and landscape development. In the last 500 years of the simulations, anthropogenic effects were introduced in the form of tillage erosion and change of vegetation type to croplands. These periods loosely reflect Holocene soil development and intensive land management starting after the Middle Ages.

For the overview, the simulated geomorphic processes were water erosion and sedimentation, soil creep, tree throw in

75 forested areas and tillage in the agricultural phase, while the simulated pedogenic processes were clay translocation, bioturbation and soil organic matter cycling. In the results I will focus on the following soil properties: soil organic matter (SOM) stocks $\left[\mathrm{kg} \mathrm{m}^{-2}\right]$, which represent a relatively fast changing property, and the depths to the Bt horizon [m], which represent a relatively slow changing property.

\subsection{Evolutionary pathways}

80 I calculated two types of evolutionary pathways to quantify the development of the soil properties: soil complexity and soillandscape development stage (Figure 1). Soil development is spatially variable, because its drivers are spatially variable as well. Therefore, I used the spatial average of a soil property $\mathrm{x}$ to measure the stage of soil property development in the entire landscape. I named this average development the soil-landscape development stage (SLDS). Changes in the SLDS can follow progressive and regressive pathways (Johnson and Watson-Stegner, 1987; Phillips, 1993; Sommer et al., 2008; Sauer,

85 2015). Progressive development indicates forward development of a property, such as soil deepening and carbon uptake, 
while regressive development indicates reduction of a certain property, such as soil loss by erosion and carbon loss. I calculated the SLDS by taking the average level of development of a certain soil property $x$ in space at a certain moment $t$ in time (Eq. (1)). Positive changes in SLDS over time indicate progressive evolution, while negative changes indicate regressive evolution (Figure 1).

$\Delta S L D S_{x, t}=\frac{\operatorname{mean}(x)_{t}-\operatorname{mean}(x)_{t-\Delta t}}{\Delta t}$

Soil complexity describes the level of variation or heterogeneity of soil and terrain properties in space (Phillips, 2017). Changes in soil complexity are driven by changes in soil forming factors, nonlinearity in pedogenic processes, internal feedbacks in the soil-landscape system and anthropogenic disturbances. I calculated the complexity as the standard deviation of a certain soil property $\mathrm{x}$ in space at a certain moment $\mathrm{t}$ in time (Eq. (2)). Positive changes in complexity over time indicate 95 divergent evolution, while negative changes indicate convergent evolution of the soil property (Figure 1, Temme et al., 2015; Phillips, 2017).

$\Delta$ complexity $_{x, t}=\frac{s d(x)_{t}-s d(x)_{t-\Delta t}}{\Delta t}$

The evolutionary pathways were calculated for timespans $\Delta t$ of 500 years in the natural phase and 50 years in the agricultural phase.

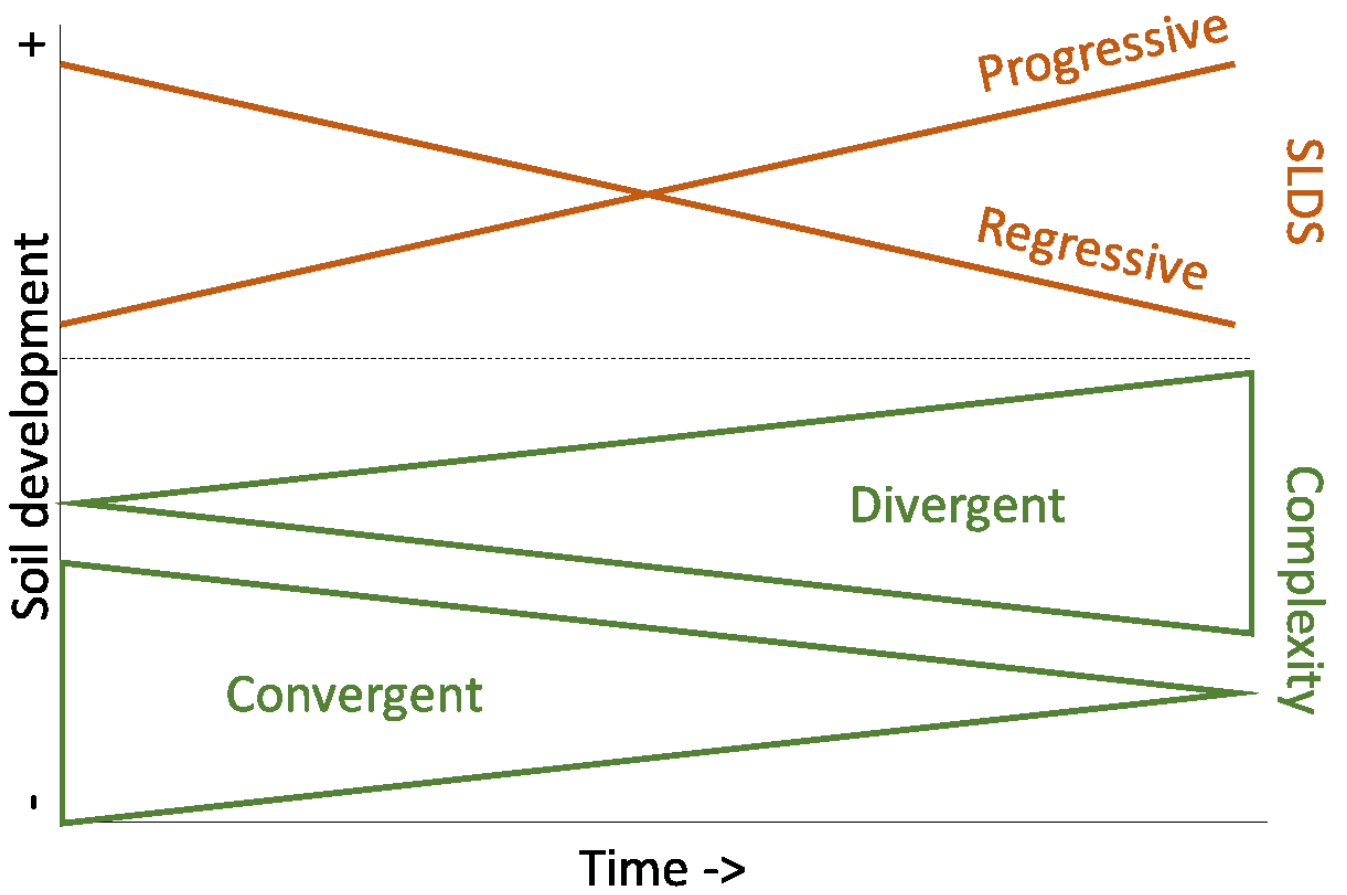

100

Figure 1: Illustration of evolutionary pathways related to SLDS and soil complexity. 


\section{Results}

Figure 2 shows the changes in SLDS and soil complexity, i.e. the evolutionary pathways, of the studied soil properties. The depth to the Bt horizon shows large differences between the dry and wet scenario in the natural phase (Figure 2A). Depths to the Bt horizon both show higher average values (higher SLDS) and higher standard deviation (higher complexity) than the dry scenario. After the start of the agricultural phase, the pattern of depth to Bt shows increasing complexity and slightly increasing SLDS for the dry scenario, while for the wet scenario, the complexity initially decreases and starts to increase again slightly 250 years into the agricultural phase. The SLDS of depth to Bt in the agricultural phase is continually decreasing for the wet scenario, while there is a slight increase in the agricultural phase in the dry scenario.

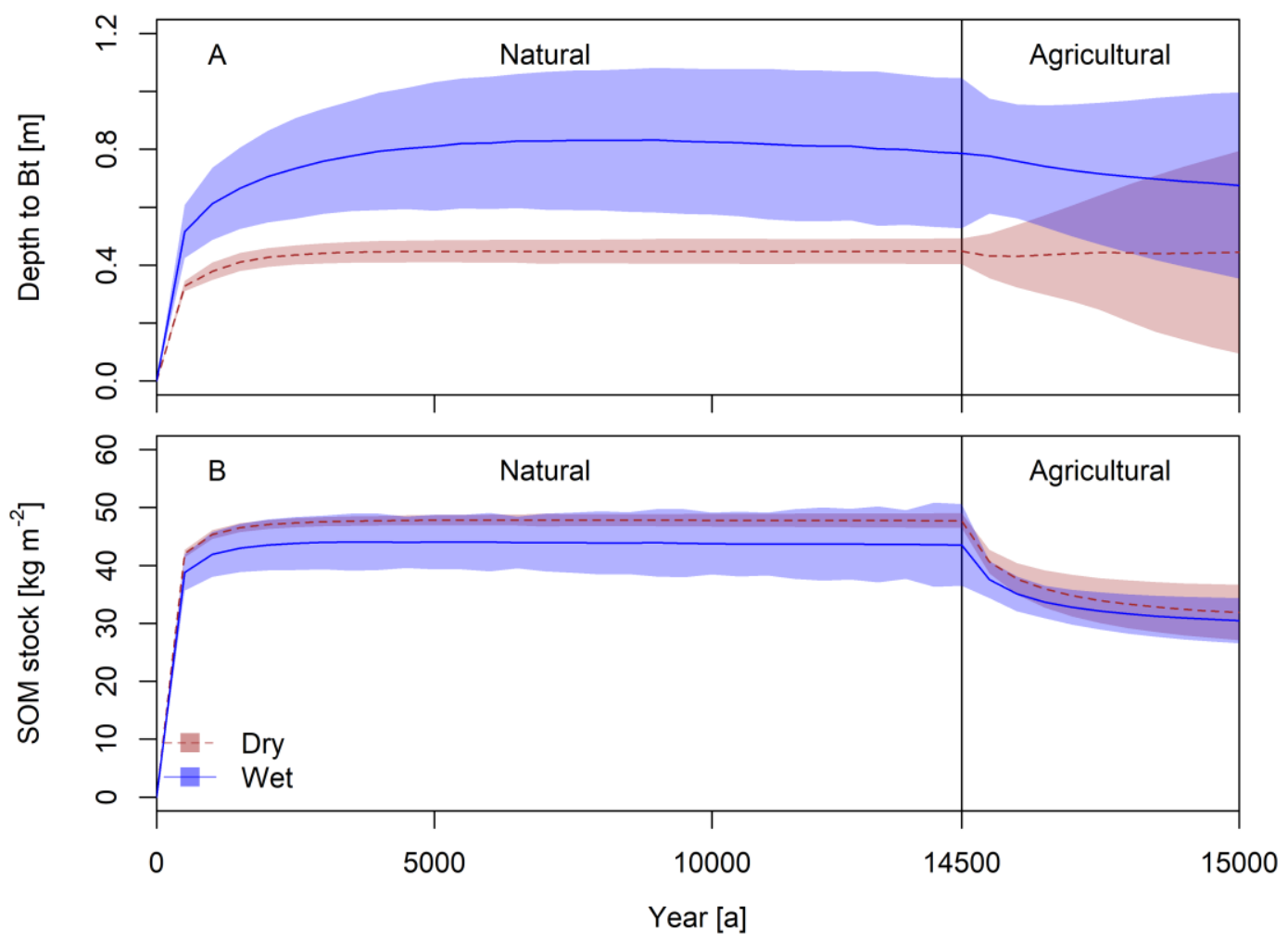

Figure 2: Evolution of the depth of the Bt horizon (A) and the SOM stocks (B) in the simulations with HydroLorica. The line indicates the average (SLDS), the polygon indicates the standard deviation (complexity). Note that the $x$-axis scale of the agricultural phase is exaggerated 10 times to visualize both systems.

115 The differences in SOM stocks between both scenarios is much smaller (Figure 2B). The dry scenario show stocks with higher SLDS and lower complexity in the natural phase, due to higher SOM input in grassland systems and less redistribution processes. The wet scenario shows a higher complexity, which is increasing slightly over time. After the start of the agricultural phase, SOM stocks in both scenarios plummet to a lower level and the complexity decreases for the wet scenario, while the complexity increases for the dry scenario. 
https://doi.org/10.5194/soil-2021-133

Preprint. Discussion started: 24 November 2021

(c) Author(s) 2021. CC BY 4.0 License.

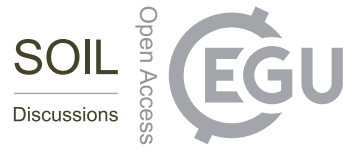

120 Figure 3 further specifies the evolutionary pathways in the model results. The pathways are displayed in quadrants, where each quadrant is a unique combination of changes in complexity and SLDS. The points in each quadrant, connected by lines, show how the soil properties evolve via different evolutionary pathways. When the points converge to the origin of the graph, the soil pattern reaches a steady state in its development. When the points converge to a point elsewhere in the graph, the soil pattern has a steady rate of change.
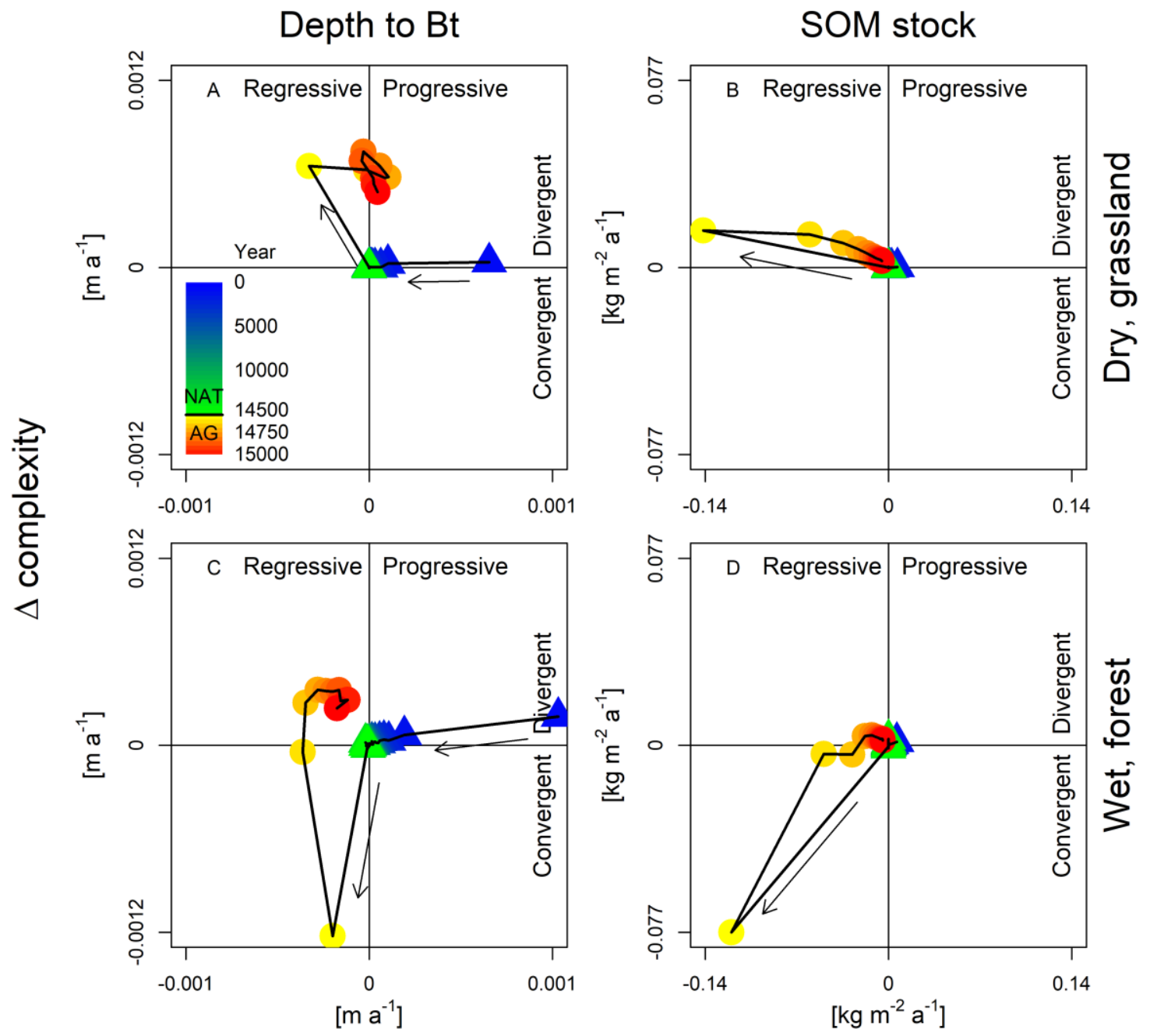

\section{$\Delta$ SLDS}

125

Figure 3: Changes in SLDS (X-axis) and complexity (Y-axis) for depth to the Bt horizon (A, C) and SOM stocks (B, D) for both rainfall scenarios (dry: A, B; wet: C, D). The colors of the symbols indicate the year. The symbols themselves indicate the land use (triangles: natural, year 0-14500; circles: agricultural, year 14 500-15 000) 
130 Natural evolutionary pathways of both soil properties in the dry scenarios, with dominant grassland vegetation, converge to a steady state at the origin of the graphs (Figure $3 \mathrm{~A} \& \mathrm{~B}$ ). Both pathways are dominantly progressive and there is little change in the complexity of the soil patterns. The SOM stocks converge faster than the depths to Bt horizons. In contrast, the natural evolutionary pathways in the wet scenario are more divergent and only converge slowly to the origin of the graph (Figure $3 C \& D)$. The evolutionary pathways remain slightly scattered in the regressive and progressive domains around the origin.

135 The changes in complexity remain slightly divergent.

In the natural phase, the largest changes in soil properties occur at the start of soil development. For each plot in Figure 3, the first step in natural soil development shows the largest changes. However, the magnitude of long-term natural soil change is often minor compared to soil change after cultivation of the land. The first step after cultivation equals or exceeds the first step of initial soil development (Figure 3). All changes in the agricultural system initially show minor to major regressive

140 soil development, which indicates that overall, soils have less SOM and shallower Bt horizons. These changes are driven by lower SOM input, redistribution and export of soil material and potential clay translocation in colluvial positions. Depending on the climatic setting, the initial change in complexity is either divergent (dry) or convergent (wet). The response of evolutionary pathways due to anthropogenic forcing thus depends on the properties of the natural soil pattern. If the natural soil pattern was already complex, such as in forested systems, initial tillage erosion and land management reduced this

145 complexity. After this initial change, all pedogenic pathways turned divergent and approached a new steady state (Figure $3 \mathrm{~B} \& \mathrm{D})$ or approached a steady rate of change (Figure $3 \mathrm{~A} \& \mathrm{C}$ ). 


\section{Discussion}

\subsection{Evolutionary pathways}

150 The model results show the effects of rainfall and land use on soil pattern development. In the natural phase, increased precipitation leads to more overland flow and higher infiltration rates. The higher rates increase water erosion and clay translocation. The higher availability of water also facilitates tree growth and consequently tree throw, which is a process that constantly changes the local spatial variation of the soil properties, preventing the reaching of a steady state. These patterns correspond to findings where local perturbations can induce divergent soil development (Phillips, 2001; Šamonil et al., 2018). The rates of local perturbations, or random processes, exceed the capacity of pedogenic processes to respond to these perturbations, causing dominant divergent soil development in the wet scenario (Phillips, 2017). The rates and direction of natural soil development are thus a function of their environmental drivers. This is well visible in Figure 3, where higher precipitation leads to more divergent evolutionary pathways that take longer to approach an equilibrium. The introduction of tillage and agricultural crops had a huge impact on the development of the soil patterns in the model. SOM stocks went down due to a lower input and increased erosion. The depths to the Bt horizon also decreased due to erosion on the hillslopes. The erosion increased the spatial variability of the soil properties (Figure 6 in Van der Meij et al., 2020), but because eroded soils cover a larger area than the colluvial soils, the depth to the Bt initially decreased on average in all simulations. The increasing spatial heterogeneity caused strongly divergent evolution in the dry scenarios, while the soil properties in the wet scenario initially followed a convergent pathway.

Most changes in the natural phase occur in the first 500 years of soil development. These findings conform to those from other studies, where initial soil development occurs with high rates, because the soil system is far from equilibrium and initial soils contain more reactive surfaces than soils in older settings (Dümig et al., 2011; Kabala and Zapart, 2012; Elmer et al., 2013). Over time, the soil properties approach an equilibrium or steady state, where the SLDS and complexity remain relatively constant. The model simulations show that a steady state in soil formation can indeed be reached, but only for faster changing properties, such as SOM stocks, and under stable circumstances with little to no external perturbations, and it is a rare occurrence (Phillips, 2010; Sauer, 2015). In the agricultural phase, the changes in the soil properties equal or exceed those of the initial soil development. This supports that human impact on soils far exceeds any natural rate of soil development (Wilkinson, 2005; Nearing et al., 2017).

The findings suggest that soils do not necessarily evolve to mature climax soils, but rather that soil patterns diverge to stable complexity. The spatial configuration of soil properties might change, but the pattern characteristics stay the same. This complexity is a function of disturbance cycles in the landscape, such as tree throw occurrences or tillage practices (Phillips, 2017). When disturbance rates are high, as is the case in intensively managed landscapes, the complexity of patterns of slowly responding soil properties keeps changing, indicating a transient state, while patterns of faster responding soil properties might reach a new steady state of stable complexity. A simple distinction between natural progressive and agricultural regressive soil development (e.g., Sommer et al., 2008) does not do justice to these complex responses of 
different soil properties to natural or anthropogenic forcing. The response of soils to local disturbances or sudden shifts in boundary conditions depends on the rates of erosion and the ability of soil properties to recover from these disturbances. Therefore, assessment of evolution of soils and landscapes should be done per individual process or soil property rather than for the entire soil and should be performed on a landscape scale rather than a pedon scale. These findings might help develop sustainable land management practices, when the models are validated and there is confidence on the functioning of the model. This can for example help evaluating the spatial and temporal effects of soil management practices for promoting carbon uptake in the soil or reducing land degradation (Minasny et al., 2017; Smetanová et al., 2019).

\subsection{Applicability for (soil-)landscape evolution modelling}

The continuous development of numerical models and quantitative data analysis techniques help increase our understanding of complex soil development under changing boundary conditions (Krasilnikov and Targulian, 2019), the functions that soils provide (Vogel et al., 2018) and improve communication of complex soil science with policy makers (Turner, 2021). Evolutionary pathways are a novel and promising way to summarize and communicate large data output into understandable trends. This work shows the potential of evolutionary pathways for summarizing large data output from numerical soillandscape evolution models into manageable and understandable trends. This evaluation on a landscape scale considers the overall development of the soil landscape with the SLDS, as well as the variation in the landscape with the complexity. By combining these two properties, a combined spatiotemporal overview of the model results is provided, while, traditionally, model output is presented only spatially (e.g., transects) or only temporally (e.g., development of a certain soil profile, time series).

In this paper, I focused on two soil properties, but the method can be applied to a wide range of properties. Examples of other properties that can be described with evolutionary pathways are simple topographic properties such as slope profiles, more complex topographic properties such as topographic position index, topographic wetness index or flow accumulation, or output maps of elevation change due to different soil erosion processes. With that, the method is applicable to the results from other (soil-)landscape evolution models or erosion models as well (Temme et al., 2017). Calculating evolutionary pathways is not even limited to soil or geomorphological systems (Phillips, 2016). As long as quantitative spatial and temporal data of model output is present, evolutionary pathways can be determined.

The easily calculatable complexity and SLDS already provide new valuable insights into changes of the state and heterogeneity of soil and landscape patterns. The calculations of evolutionary pathways are of course not limited to the mean and standard deviation of these patterns. Other, more complex, statistics can provide additional insights in other properties of soil patterns. For example, changes in the parameters of semivariograms, i.e. the nugget, sill and range, can provide insights

210 in the development of local and regional spatial autocorrelation of soil properties. Changes in correlations between soil properties and terrain properties or boundary conditions, can help shed new light on the spatial and temporal dependence of soil properties on external parameters. These findings might improve statistical soil prediction models by introducing more mechanistic process understanding (Angelini et al., 2016; Ma et al., 2019). 
https://doi.org/10.5194/soil-2021-133

Preprint. Discussion started: 24 November 2021

(c) Author(s) 2021. CC BY 4.0 License.

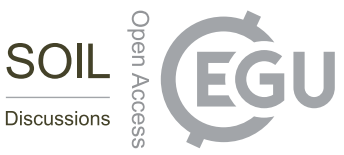

Validation of soil-landscape evolution models is a difficult task, because validation data should cover the parameter domain,

215 spatial domain and temporal domain of these models (Minasny et al., 2015). Field data for some, or all, of these domains are often not available, because data over long timescales is missing, simulated scenarios cover periods of time that are currently not visible or detectable anymore, or SLEMs cover too many different processes and parameters for the available data to calibrate and validate. Here, the evolutionary pathways might provide a solution as well. Temme et al. (2017) suggest that simulated pathways might be constrained using field observations. The complexity or SLDS at a measurable moment in

220 space and time might be used to evaluate the model results for that same moment. When performing explorative modelling, where a simple model is run multiple times with varying inputs (e.g., Larsen et al., 2014), the model results can be converted into evolutionary pathways that can be rejected or accepted using field evidence. These are two ways to ensure a better connection between model and field data, which is currently lacking for most soil-landscape evolution models (Minasny et al., 2015). 
https://doi.org/10.5194/soil-2021-133

Preprint. Discussion started: 24 November 2021

(c) Author(s) 2021. CC BY 4.0 License.

(c) (1)

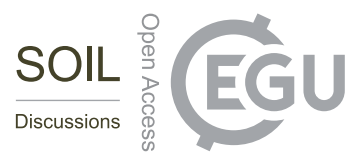

\section{Conclusions}

In this study, I used evolutionary pathways to summarize and conceptualize spatial and temporal trends in previously published results from a soil-landscape evolution model. The evolutionary pathways indicate progressive or regressive soil development and convergence or divergence of the soil pattern, as a consequence of (non-linear) changes in the drivers of

230 soil and landscape development. The evolutionary pathways can be linked to real-world examples of soil development and soil complexity.

Evolutionary pathways are not limited to the examples presented in this study, but can be applied to a wide range of soil pattern statistics and soil and terrain properties. With this, evolutionary pathways provide a promising tool to communicate soil model output, not only for studying past changes in soils, but also for evaluating future spatial and temporal effects of

235 soil management practices in the context of sustainability.

\section{Competing interests}

The author declares that he has no conflict of interest.

\section{Code availability}

See Van der Meij et al., (2020) for model code availability.

\section{Acknowledgements}

This paper forms the completion of my $\mathrm{PhD}$ on soil and landscape evolution in the Anthropocene. I want to thank my supervisors dr. Arnaud Temme, prof.dr. Michael Sommer and prof.dr. professor Jakob Wallinga for their supervision and support during my $\mathrm{PhD}$. 
https://doi.org/10.5194/soil-2021-133

Preprint. Discussion started: 24 November 2021

(c) Author(s) 2021. CC BY 4.0 License.

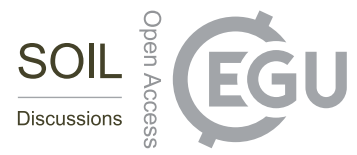

\section{References}

Adhikari, K. and Hartemink, A. E.: Linking soils to ecosystem services - A global review, Geoderma, 262, 101-111, https://doi.org/10.1016/j.geoderma.2015.08.009, 2016.

Angelini, M. E., Heuvelink, G. B. M., Kempen, B., and Morrás, H. J. M.: Mapping the soils of an Argentine Pampas region using structural equation modelling, Geoderma, 281, 102-118, https://doi.org/10.1016/j.geoderma.2016.06.031, 2016.

250 Bock, M., Conrad, O., Günther, A., Gehrt, E., Baritz, R., and Böhner, J.: SaLEM (v1.0) - the Soil and Landscape Evolution Model (SaLEM) for simulation of regolith depth in periglacial environments, Geosci. Model Dev., 11, 1641-1652, https://doi.org/10.5194/gmd-11-1641-2018, 2018.

Bouchoms, S., Wang, Z., Vanacker, V., Doetterl, S., and Van Oost, K.: Modelling long-term soil organic carbon dynamics under the impact of land cover change and soil redistribution, CATENA, 151, 63-73, https://doi.org/10.1016/j.catena.2016.12.008, 2017.

Dotterweich, M.: The history of human-induced soil erosion: Geomorphic legacies, early descriptions and research, and the development of soil conservation-A global synopsis, Geomorphology, 201, 1-34, https://doi.org/10.1016/j.geomorph.2013.07.021, 2013.

Dümig, A., Smittenberg, R., and Kögel-Knabner, I.: Concurrent evolution of organic and mineral components during initial soil development after retreat of the Damma glacier, Switzerland, Geoderma, 163, 83-94, https://doi.org/10.1016/j.geoderma.2011.04.006, 2011.

Elmer, M., Gerwin, W., Schaaf, W., Zaplata, M. K., Hohberg, K., Nenov, R., Bens, O., and Hüttl, R. F.: Dynamics of initial ecosystem development at the artificial catchment Chicken Creek, Lusatia, Germany, Environ. Earth Sci., 69, 491-505, https://doi.org/10.1007/s12665-013-2330-2, 2013.

265 Johnson, D. L. and Watson-Stegner, D.: Evolution model of pedogenesis, Soil Sci., 143, 349-366, https://doi.org/10.1097\%2F00010694-198705000-00005, 1987.

Kabala, C. and Zapart, J.: Initial soil development and carbon accumulation on moraines of the rapidly retreating Werenskiold Glacier, SW Spitsbergen, Svalbard archipelago, Geoderma, 175, 9-20, https://doi.org/10.1016/j.geoderma.2012.01.025, 2012.

270 Krasilnikov, P. V. and Targulian, V. O.: Towards "New Soil Geography": Challenges and Solutions. A Review, Eurasian Soil Sci., 52, 113-121, https://doi.org/10.1134/S1064229319020091, 2019.

Larsen, L., Thomas, C., Eppinga, M., and Coulthard, T.: Exploratory Modeling: Extracting Causality From Complexity, Eos Trans. Am. Geophys. Union, 95, 285-286, https://doi.org/10.1002/2014EO320001, 2014.

Ma, Y., Minasny, B., Malone, B. P., and Mcbratney, A. B.: Pedology and digital soil mapping (DSM), Eur. J. Soil Sci., 70,

216-235, https://doi.org/10.1111/ejss.12790, 2019.

Minasny, B., Finke, P., Stockmann, U., Vanwalleghem, T., and McBratney, A. B.: Resolving the integral connection between pedogenesis and landscape evolution, Earth-Sci. Rev., 150, 102-120, https://doi.org/10.1016/j.earscirev.2015.07.004, 2015.

Minasny, B., Malone, B. P., McBratney, A. B., Angers, D. A., Arrouays, D., Chambers, A., Chaplot, V., Chen, Z.-S., Cheng, K., Das, B. S., Field, D. J., Gimona, A., Hedley, C. B., Hong, S. Y., Mandal, B., Marchant, B. P., Martin, M., McConkey, B. 
https://doi.org/10.5194/soil-2021-133

Preprint. Discussion started: 24 November 2021

(c) Author(s) 2021. CC BY 4.0 License.

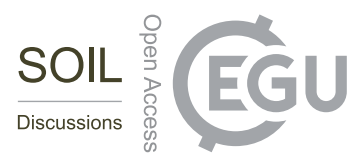

G., Mulder, V. L., O’Rourke, S., Richer-de-Forges, A. C., Odeh, I., Padarian, J., Paustian, K., Pan, G., Poggio, L., Savin, I., Stolbovoy, V., Stockmann, U., Sulaeman, Y., Tsui, C.-C., Vågen, T.-G., Van Wesemael, B., and Winowiecki, L.: Soil carbon 4 per mille, Geoderma, 292, 59-86, https://doi.org/10.1016/j.geoderma.2017.01.002, 2017.

Nearing, M. A., Xie, Y., Liu, B., and Ye, Y.: Natural and anthropogenic rates of soil erosion, Int. Soil Water Conserv. Res., 5, 77-84, https://doi.org/10.1016/j.iswcr.2017.04.001, 2017.

Phillips, J. D.: Progressive and Regressive Pedogenesis and Complex Soil Evolution, Quat. Res., 40, 169-176, https://doi.org/10.1006/qres.1993.1069, 1993.

Phillips, J. D.: Divergent evolution and the spatial structure of soil landscape variability, CATENA, 43, 101-113, https://doi.org/10.1016/S0341-8162(00)00122-3, 2001.

290 Phillips, J. D.: The convenient fiction of steady-state soil thickness, Geoderma, 156, 389-398, https://doi.org/10.1016/j.geoderma.2010.03.008, 2010.

Phillips, J. D.: Complexity of Earth Surface System Evolutionary Pathways, Math. Geosci., 48, 743-765, https://doi.org/10.1007/s11004-016-9642-1, 2016.

Phillips, J. D.: Soil Complexity and Pedogenesis, Soil Sci., 182, 1, https://doi.org/10.1097/SS.0000000000000204, 2017.

295 Phillips, J. D.: Evolutionary Pathways in Soil-Geomorphic Systems, Soil Sci., 184, 1-12, https://doi.org/10.1097/SS.0000000000000246, 2019.

Šamonil, P., Daněk, P., Schaetzl, R. J., Tejnecký, V., and Drábek, O.: Converse pathways of soil evolution caused by tree uprooting: A synthesis from three regions with varying soil formation processes, CATENA, 161, 122-136, https://doi.org/10.1016/j.catena.2017.09.032, 2018.

300 Sauer, D.: Pedological concepts to be considered in soil chronosequence studies, Soil Res., 53, 577-591, https://doi.org/10.1071/SR14282, 2015.

Smetanová, A., Follain, S., David, M., Ciampalini, R., Raclot, D., Crabit, A., and Le Bissonnais, Y.: Landscaping compromises for land degradation neutrality: The case of soil erosion in a Mediterranean agricultural landscape, J. Environ. Manage., 235, 282-292, https://doi.org/10.1016/j.jenvman.2019.01.063, 2019.

305 Sommer, M., Gerke, H. H., and Deumlich, D.: Modelling soil landscape genesis — A "time split" approach for hummocky agricultural landscapes, Geoderma, 145, 480-493, https://doi.org/10.1016/j.geoderma.2008.01.012, 2008.

Stephens, L., Fuller, D., Boivin, N., Rick, T., Gauthier, N., Kay, A., Marwick, B., Armstrong, C. G., Barton, C. M., Denham, T., Douglass, K., Driver, J., Janz, L., Roberts, P., Rogers, J. D., Thakar, H., Altaweel, M., Johnson, A. L., Sampietro Vattuone, M. M., Aldenderfer, M., Archila, S., Artioli, G., Bale, M. T., Beach, T., Borrell, F., Braje, T., Buckland, P. I.,

310 Jiménez Cano, N. G., Capriles, J. M., Diez Castillo, A., Çilingiroğlu, Ç., Negus Cleary, M., Conolly, J., Coutros, P. R., Covey, R. A., Cremaschi, M., Crowther, A., Der, L., di Lernia, S., Doershuk, J. F., Doolittle, W. E., Edwards, K. J., Erlandson, J. M., Evans, D., Fairbairn, A., Faulkner, P., Feinman, G., Fernandes, R., Fitzpatrick, S. M., Fyfe, R., Garcea, E., Goldstein, S., Goodman, R. C., Dalpoim Guedes, J., Herrmann, J., Hiscock, P., Hommel, P., Horsburgh, K. A., Hritz, C., Ives, J. W., Junno, A., Kahn, J. G., Kaufman, B., Kearns, C., Kidder, T. R., Lanoë, F., Lawrence, D., Lee, G.-A., Levin, M.

315 J., Lindskoug, H. B., López-Sáez, J. A., Macrae, S., Marchant, R., Marston, J. M., McClure, S., McCoy, M. D., Miller, A. V., Morrison, M., Motuzaite Matuzeviciute, G., Müller, J., Nayak, A., Noerwidi, S., Peres, T. M., Peterson, C. E., Proctor, L., Randall, A. R., Renette, S., Robbins Schug, G., Ryzewski, K., Saini, R., Scheinsohn, V., Schmidt, P., Sebillaud, P., Seitsonen, O., Simpson, I. A., Sołtysiak, A., Speakman, R. J., Spengler, R. N., Steffen, M. L., et al.: Archaeological 
https://doi.org/10.5194/soil-2021-133

Preprint. Discussion started: 24 November 2021

(c) Author(s) 2021. CC BY 4.0 License.

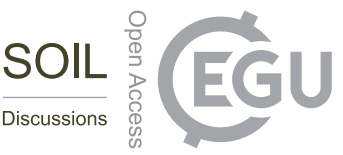

(c) (1)

assessment reveals Earth's early transformation through land use, Science, 365, 897, https://doi.org/10.1126/science.aax1192, 2019.

Temme, A. J. A. M., Lange, K., and Schwering, M. F. A.: Time development of soils in mountain landscapes - divergence and convergence of properties with age, J. Soils Sediments, 15, 1373-1382, https://doi.org/10.1007/s11368-014-0947-8, 2015 .

Temme, A. J. A. M., Armitage, J., Attal, M., Gorp, W. van, Coulthard, T. J., and Schoorl, J. M.: Developing, choosing and 325 using landscape evolution models to inform field-based landscape reconstruction studies, Earth Surf. Process. Landf., 42, 2167-2183, https://doi.org/10.1002/esp.4162, 2017.

Turner, B. L.: Soil as an Archetype of Complexity: A Systems Approach to Improve Insights, Learning, and Management of Coupled Biogeochemical Processes and Environmental Externalities, Soil Syst., 5, 39, https://doi.org/10.3390/soilsystems5030039, 2021.

330 Van der Meij, W. M., Temme, A., Lin, H. S., Gerke, H. H., and Sommer, M.: On the role of hydrologic processes in soil and landscape evolution modeling: concepts, complications and partial solutions, Earth-Sci. Rev., 185, 1088-1106, https://doi.org/10.1016/j.earscirev.2018.09.001, 2018.

Van der Meij, W. M., Temme, A. J., Wallinga, J., and Sommer, M.: Modeling soil and landscape evolution-the effect of rainfall and land-use change on soil and landscape patterns, Soil, 6, 337-358, https://doi.org/10.5194/soil-6-337-2020, 2020.

335 Vogel, H. J., Bartke, S., Daedlow, K., Helming, K., Kögel-Knabner, I., Lang, B., Rabot, E., Russell, D., Stößel, B., Weller, U., Wiesmeier, M., and Wollschläger, U.: A systemic approach for modeling soil functions, SOIL, 4, 83-92, https://doi.org/10.5194/soil-4-83-2018, 2018.

Welivitiya, W. D. D. P., Willgoose, G. R., and Hancock, G. R.: A coupled soilscape-landform evolution model: model formulation and initial results, Earth Surf. Dyn., 7, 591-607, https://doi.org/10.5194/esurf-7-591-2019, 2019.

340 Wilkinson, B. H.: Humans as geologic agents: A deep-time perspective, Geology, 33, 161-164, https://doi.org/10.1130/g21108.1, 2005. 